\title{
EFFECT OF EXTENDERS ON THE CHARACTERISTIC AND FERTILITY OF COOLD BUFFALO SEMEN
}

\author{
Ismail Ismail El-Kon 1 , , El-Sayed Mohammed Fattouh ${ }^{\text {, }}$ \\ Samy Anwer Darwish, ${ }^{2}$ and Fady samir Farag ${ }^{3}$ \\ ${ }^{1}$ Theriogenology Department, Faculty of Veterinary Medicine, \\ kafrelsheikh University, Kafr- Elsheikh -33516, Egypt. \\ ${ }^{2}$ Mehallat Mousa Buffalo Research Station, Animal Production Research \\ Institute, Ministry of Agriculture, Egypt. \\ ${ }^{2}$ General Authority for Veterinary Services, Al-Gharbia, Province, \\ Algarbia, Egypt.
}

\begin{abstract}
The present study was conducted to investigate the effect of semen extenders on the characteristics of cooled buffalo semen and to determine the suitable extender which will give higher conception rate. Semen was collected from five buffalo (5-6 years) bulls twice weekly using artificial vagina. Freshly collected semen samples were evaluated and ejaculates of at least $70 \%$ individual motility and $6 \times 10^{6}$ sperm $/ \mathrm{ml}$ were pooled, divided into three parts, diluted with tris egg yolk, citrate egg yolk or skimmed milk extender and cooled slowly to $5^{\circ} \mathrm{C}$. Semen samples were evaluated for individual motility, alive sperm, plasma and acrosomal membranes integrity as well as viability index. Conception rates of buffalo cows artificially inseminated with cooled buffalo semen were also estimated. The results of the present study revealed that semen extender and storage time exert a highly significant effects on the characteristics of cooled buffalo semen with the higher values recorded for tris egg yolk diluted samples. The
\end{abstract}


conception rate of cooled buffalo semen was significantly $(P<0.01)$ higher in tris (70\%) diluted samples than skimmed milk (60\%) and egg yolk citrate (50\%) extended samples. It was concluded that the tris egg yolk extender is the most satisfactory buffering system to improve the post-cooling semen quality in buffalo and gave the best conception rate.

Key ward: Buffalo, cooled semen, extender, fertility.

\section{INTRODUCTION}

Artificial insemination (AI) is an important tool for distribution of superior genetics.

It has been used successfully for genetic improvement of several livestock species including buffalo (Sukhato et al.,2001; Chaudhari and Mshelia, 2002). Moreover artificial insemination gained wide acceptance in the development of the livestock resources in the developing countries (Cheema and Samad, 1986 .Recent studies have shown that buffalo semen can be preserved just like bovine semen. There are a number of diluents which are suitable for preservation of buffalo semen, but there is limited information available on the semen characteristics of the species (Sansone et al., 2000). The success of semen storage depends on numerous factors which may be peculiar to each species and are optimized according to the type of semen to be preserved. Buffalo spermatozoa are more susceptible to hazards during preservation than cattle spermatozoa (Raizada et al., 1990). These hazards can be minimized by optimizing the cooling rate and using appropriate diluting media in which spermatozoa are preserved (Kumar et al., 1992). 
The ultimate goal of semen evaluation is to accurately predict its fertilizing potential. Although much progress has been made, the ability to predict the fertility of semen with laboratory tests is still limited, mainly due to the complexity of the spermatozoon and the fertilization process (Amann and Hammerstedt,1993). Fertility of buffaloes inseminated with semen was significantly higher when tris was used compared to citrate (Dhami and Kodagali, 1990) but did not differ when compared with milk extender (Dhami et al., 1996). The relative efficacy and suitability of different semen extenders for buffalo semen have been reported with varying success by many laboratories around the globe (Dhami et al., 1996). Therefore the present study was undertaken to determine the effect of semen extenders on the characteristics of cooled buffalo semen and to find out the suitable extender which will give higher fertility rate.

\section{MATERIALS AND METHODS}

\section{Semen collection:}

Five healthy buffalo bulls aged 5 to 6 years and maintained under identical nutritional and managerial conditions at Mehallet Mousa Research Station belonging to Animal Production Research Institute, Agriculture Research Center, Kafr El-Sheikh province, Egypt were used in the present study. Semen was collected twice weekly using artificial vagina

\section{Semen evaluation:}

Freshly collected semen samples were assessed for semen volume, Progressive sperm motility, alive sperm, concentration, and membrane and acrosome integrity of spermatozoa. Progressive sperm motility was 
evaluated subjectively using a phase contrast microscope $(400 \mathrm{x})$. Alive sperm percentage was determined as described previously by Campbell et al., (1956). Membrane integrity of sperm was determined by using hypo osmotic swelling (HOS) test according to Jeyendran et al., (1984). Acrosomal membrane integrity was evaluated by using eosine-nigrosin stained smear according to the method of Bamba (1988). Two hundred spermatozoa were examined from each semen sample. Sperm with crescent shape apical ridge considered having intact acrosome otherwise spermatozoa consider have damaged acrosome.

\section{Semen dilution:}

The used diluents were prepared on the day before semen collection and kept overnight at $5^{\circ} \mathrm{C}$. One hour before semen collection the diluents were warmed in a water bath at $30^{\circ} \mathrm{C}$ After collection semen was also kept warm in the same water bath and evaluated before semen processing. Only semen samples of at least $70 \%$ individual motility and $600 \times 10^{6}$ sperm cells $/ \mathrm{ml}$ were pooled and divided into three parts, part 1 was diluted with tris egg yolk extender, part 2 with citrate egg yolk and part 3 with skimmed milk extender at $30^{\circ} \mathrm{C}$ in a single stepwise in a clean dry graduated tubes. Immediately after dilution semen was evaluated for individual motility, alive sperm, plasma and acrosomal membranes integrity.

\section{Semen extenders:}

All chemical reagents employed were of the highest commercially available purity. Unless otherwise stated, all chemicals used in this study were purchased from Sigma Aldrich Co., Cairo, Egypt. 


\section{Citrate egg yolk:}

It was composed of $73.00 \mathrm{ml}$ sodium citrate buffer (prepared by dissolving $2.90 \mathrm{~g}$ tri sodium citrate dihydrate in $100.0 \mathrm{ml}$ glass-distilled water) and $20.0 \mathrm{ml}$ fresh egg yolk. Penicillin G sodium (1000.0 IU /ml; Chemical Industries Development Giza A. R. E.) and streptomycin (1.00 $\mathrm{mg} / \mathrm{ml}$; Chemical Industries Development Giza A. R. E.) sulfate (Dhami et al., 1995) were added.

\section{Tris egg yolk:}

It was composed of $80.0 \mathrm{ml}$ tris buffer (prepared by dissolving $3.028 \mathrm{~g}$ tris, $1.678 \mathrm{~g}$ citric acid and $1.00 \mathrm{~g}$ fructose in $100.0 \mathrm{ml}$ glassdistilled water) and $20.0 \mathrm{ml}$ fresh egg yolk. Penicillin G sodium and streptomycin sulfate were added at concentrations of $1000.0 \mathrm{IU} / \mathrm{ml}$ and $1.00 \mathrm{mg} / \mathrm{ml}$, respectively (Davis et al., 1963).

\section{Skimmed milk:}

It composed of $100 \mathrm{ml}$ skimmed milk with $1000.0 \mathrm{IU} / \mathrm{ml}$ penicillin G sodium and $1.00 \mathrm{mg} / \mathrm{ml}$ streptomycin sulfate (Davis et al., 1963).

\section{Cooling of semen:}

The diluted semen samples were slowly cooled to $5^{\circ} \mathrm{C}$ over a period of $2 \mathrm{~h}$. The percentages of individual sperm motility, alive sperm as well as acrosomal and plasma membranes integrity were evaluated at $6,24,48,72$ and 96 hours after cooling in addition to viability index. The viability index of cooled buffalo (Milovanove,1962) semen was calculated.

\section{Fertility of cooled buffalo semen:}

Sixty cyclic Egyptian buffalo-cows aged 4 to 5 years having normal parturition and maintained under identical nutritional and managerial 
conditions at Mehallet Mousa Research farm in KafrEl-sheikh province, Egypt were used in the present study. These animals are allocated into three groups each of 20 and all animals represent estrous signs. They were artificially inseminated during heat with cooled semen (after 96h. of storage) diluted with one of the three used extenders. Pregnancy diagnosis was carried out by palpation per rectum 45 days postinsemination.

\section{Synchronization of estrous:}

Estrous was synchronized by using double injection of $25 \mathrm{mg}$ natural prostaglandin F2 a (Lutalyse TM; Dinoprost. Tromethamin. $5 \mathrm{mg} / \mathrm{ml}$; Upjohn Co.) Per animal with 11 days interval. Estrous was detected by well trained herd man. All animals were observed twice daily (at morning and afternoon) for about one hour each time (Vale et al., 1990).

\section{Statistical analysis:}

Data were analyzed by least squares procedures using the general linear models procedures of SPSS/PCT and M. Stat software. All data were subjected to analysis of variance (ANOVA) to clarify the effect of semen extenders on sperm motility, alive sperm, acrosomal and plasma membranes integrity as well as viability index. Conception rate results were analyzed by the chi-square test.

\section{RESULTS}

\section{Individual progressive motility:}

Table 1 shows the individual progressive motility of buffalo spermatozoa immediately after dilution and during storage at $5^{\circ} \mathrm{C}$. Analysis of variance revealed that there were a highly $(\mathrm{P}<0.01)$ 
significant effects due to semen extenders, time of storage as well as interaction between them. The percentage of individual sperm motility was not significantly differed after dilution until $6 \mathrm{~h}$ of storage after cooling. The lowest $(24.66 \%)$ value was recorded at $96 \mathrm{~h}$ of storage at $5^{\circ} \mathrm{C}$ for citrate egg yolk extender.

\section{Alive sperm of buffalo semen:}

The percentages of alive sperm of buffalo semen is presented in Table 2, no significant effect was found (ANOVA) for the time-extender interaction on the percentages of alive sperm of buffalo semen while highly $(\mathrm{P}<0.01)$ significant effect was reported for the time of storage and significant $(\mathrm{P}<0.05)$ for the semen extenders. There were no significant changes on the percentages of alive sperm up to $24 \mathrm{~h}$ of storage at $5^{\circ} \mathrm{C}$ and the lowest value $(54.78 \%)$ was recorded at $96 \mathrm{~h}$ for citrate egg yolk extender.

Table (1): Percentage of individual motility of buffalo semen immediately after dilution and after cooling at $5^{\circ} \mathrm{C}$.

\begin{tabular}{|c||c||c|c|c|c|c|c||}
\hline \multirow{2}{*}{$\begin{array}{c}\text { Semen } \\
\text { extender }\end{array}$} & \multirow{2}{*}{$\begin{array}{c}\text { After } \\
\text { dilution } \\
\left(30^{\circ} \mathrm{C}\right)\end{array}$} & 6 & 24 & 48 & 72 & 96 & $\begin{array}{c}\text { Overall } \\
\text { mean }\end{array}$ \\
\cline { 3 - 8 } & 72.00 & 68.83 & 63.33 & 56.00 & 47.16 & 27.16 & 52.50 \\
\hline \hline $\begin{array}{c}\text { Skimmed } \\
\text { milk }\end{array}$ & $\pm 0.85^{\mathrm{aA}}$ & $\pm 0.98^{\mathrm{b}}$ & $\pm 1.67^{\mathrm{c}}$ & $\pm 1.95^{\mathrm{d}}$ & $\pm 2.61^{\mathrm{e}}$ & $\pm 3.47^{\mathrm{f}}$ & $\pm 1.56^{\mathrm{A}}$ \\
\hline Tris & 70.33 & 65.33 & 60.50 & 53.33 & 44.33 & $36.16 \pm$ & 51.93 \\
egg yolk & $\pm 0.98^{\mathrm{aBC}}$ & $\pm 1.33^{\mathrm{b}}$ & $\pm 1.50^{\mathrm{c}}$ & $\pm 1.79^{\mathrm{d}}$ & $\pm 2.33^{\mathrm{e}}$ & $2.53^{\mathrm{f}}$ & $\pm 1.22^{\mathrm{A}}$ \\
\hline Citrate & 69.16 & 60.66 & 53.66 & 45.83 & 35.66 & $24.66 \pm$ & 44.51 \\
Egg yolk & $\pm 0.93^{\mathrm{aC}}$ & $\pm 1.63^{\mathrm{b}}$ & $\pm 1.96^{\mathrm{c}}$ & $\pm 2.04^{\mathrm{d}}$ & $\pm 2.29^{\mathrm{e}}$ & 2.60 & $\pm 1.40^{\mathrm{B}}$ \\
\hline \hline
\end{tabular}

Values are mean \pm SEM $(n=120)$

Means having different capital $(\mathrm{P}<0.01)$ or small letters $(\mathrm{P}<0.05)$

$\overline{\text { Kafrelsheikh Vet. Med. J. Vol. } 6 \text { No. } 2 \text { (2008) }}$ 
within the same column or row are significantly different.

Table(2): Percentage of alive sperm of buffalo semen immediately after dilution and after cooling at $5^{\circ} \mathrm{C}$

\begin{tabular}{|c|c|c|c|c|c|c|c|}
\hline \multirow{2}{*}{$\begin{array}{c}\text { Semen } \\
\text { extender }\end{array}$} & $\begin{array}{c}\text { After } \\
\text { dilution }\end{array}$ & \multicolumn{6}{|c|}{ Storage time(hours) at $5^{\circ} \mathrm{C}$} \\
\hline & & 6 & 24 & 48 & 72 & 96 & $\begin{array}{c}\text { Overall } \\
\text { mean }\end{array}$ \\
\hline Skimmed & 76.41 & 73.88 & 71.10 & 67.86 & 63.56 & 56.13 & 66.11 \\
\hline milk & $\pm 1.18^{\mathrm{aA}}$ & $\pm 1.18^{\mathrm{b}}$ & $\pm 1.29^{\mathrm{b}}$ & $\pm 1.26^{\mathrm{c}}$ & $\pm 1.78^{\mathrm{c}}$ & $\pm 2.76^{\mathrm{d}}$ & $\pm 0.96^{\mathrm{AB}}$ \\
\hline Tris & 75.43 & 73.66 & 70.93 & 67.86 & 64.80 & 60.3 & 67.52 \\
\hline egg yolk & $\pm 0.98^{\mathrm{aBC}}$ & $\pm 1.20^{\mathrm{b}}$ & $\pm 1.40^{\mathrm{b}}$ & $\pm 1.59^{\mathrm{c}}$ & $\pm 1.69^{\mathrm{c}}$ & $\pm 1.98^{\mathrm{d}}$ & $\pm 0.80^{\mathrm{A}}$ \\
\hline Citrate & 73.56 & 71.43 & 69.65 & 66.30 & 62.00 & 54.78 & 64.83 \\
\hline Egg yolk & $\pm 0.90^{\mathrm{aC}}$ & $\pm 1.10^{\mathrm{b}}$ & $\pm 1.15^{\mathrm{b}}$ & $\pm 1.25^{\mathrm{c}}$ & $\pm 1.67^{\mathrm{c}}$ & \pm 2.86 & $\pm 0.91^{\mathrm{B}}$ \\
\hline
\end{tabular}

Values are mean \pm SEM $(n=120)$

Means having different capital $(\mathrm{P}<0.01)$ or small letters $(\mathrm{P}<0.05)$

within the same column or row are significantly different.

\section{Plasma membrane integrity:}

Concerning the effect of semen extenders and time of storage on the percentages of intact plasma membrane (Table 3) analysis of variance revealed that there was non significant effects for the semen extenders and the interaction between time and extender, while the storage time exerts a highly $(\mathrm{P}<0.01)$ significant effect. The percentages of intact plasma membrane did not differ significantly after dilution up to $6 \mathrm{~h}$ of storage at $5^{\circ} \mathrm{C}$; moreover there were no significant changes during 
the storage time from 24 to $72 \mathrm{~h}$. However, there were highly significant changes between $96 \mathrm{~h}$ and any other time.

\section{Acrosomal membrane integrity:}

The percentages of intact acrosomal membrane of buffalo spermatozoa is presented in Table 4, no significant effect was found (ANOVA) for the time-extender interaction on the percentages of intact plasma membrane of buffalo spermatozoa while highly $(\mathrm{P}<0.01)$ significant effect was reported for the time of storage and significant $(\mathrm{P}<0.05)$ for the semen extenders. There were no significant changes on the percentages of intact plasma membrane of buffalo spermatozoa up to $24 \mathrm{~h}$ of storage at $5^{\circ} \mathrm{C}$ and the lowest $(46.96 \%)$ value was recorded at 96 $\mathrm{h}$ for citrate egg yolk extender.

\section{Viability index:}

The viability index of buffalo spermatozoa stored 96 hours after cooling at $5^{\circ} \mathrm{C}$ is presented in Table 5. Average values of 112.26, 116.06 and 94.58 were recorded for skimmed milk, tris egg yolk and citrate egg yolk diluted samples, respectively. Analysis of variance revealed that the extenders exert a highly $(\mathrm{P}<0.01)$ significantly effect on the viability index of buffalo spermatozoa stored at $5^{\circ} \mathrm{C}$ for 96 hours.

Table (3): Percentage of intact plasma membrane (tail swelling) of diluted and cooled buffalo semen

\begin{tabular}{|c|c|c|c|c|c|c|c|}
\hline \multirow{2}{*}{$\begin{array}{l}\text { Semen } \\
\text { extender }\end{array}$} & \multirow{2}{*}{$\begin{array}{c}\text { After } \\
\text { dilution } \\
\left(30^{\circ} \mathrm{C}\right)\end{array}$} & \multicolumn{6}{|c|}{ Storage time(hours) at $5^{\circ} \mathrm{C}$} \\
\hline & & 6 & 24 & 48 & 72 & 96 & $\begin{array}{c}\text { Overall } \\
\text { mean }\end{array}$ \\
\hline $\begin{array}{c}\text { Skimmed } \\
\text { milk }\end{array}$ & $\begin{array}{c}71.53 \\
\pm 0.47^{\mathrm{aC}} \\
\end{array}$ & $\begin{array}{r}70.63 \\
\pm 0.72^{\mathrm{a}} \\
\end{array}$ & $\begin{array}{c}67.66 \\
\pm 0.90^{\mathrm{b}} \\
\end{array}$ & $\begin{array}{r}65.08 \\
\pm 0.86^{\mathrm{b}} \\
\end{array}$ & $\begin{array}{c}63.10 \\
\pm 1.008^{\mathrm{b}} \\
\end{array}$ & $\begin{array}{r}60.65 \\
\pm 0.90^{c} \\
\end{array}$ & $\begin{array}{r}65.41 \\
\pm 0.48^{\mathrm{B}} \\
\end{array}$ \\
\hline $\begin{array}{c}\text { Tris } \\
\text { egg yolk }\end{array}$ & $\begin{array}{c}74.66 \\
\pm 0.68 \text { aA } \\
\end{array}$ & $\begin{array}{r}73.76 \\
\pm 0.67^{\text {a }} \\
\end{array}$ & $\begin{array}{c}70.70 \\
\pm 0.79^{\mathrm{b}} \\
\end{array}$ & $\begin{array}{r}68.36 \\
\pm 0.98^{\mathrm{b}} \\
\end{array}$ & $\begin{array}{c}65.86 \\
\pm 1.08^{\mathrm{b}} \\
\end{array}$ & $\begin{array}{r}63.86 \\
\pm 1.13^{\mathrm{c}} \\
\end{array}$ & $\begin{array}{r}68.51 \\
\pm 0.50^{\mathrm{A}} \\
\end{array}$ \\
\hline $\begin{array}{c}\text { Citrate } \\
\text { Egg yolk }\end{array}$ & $\begin{array}{c}73.46 \\
\pm 0.95^{\mathrm{aAB}} \\
\end{array}$ & $\begin{array}{r}72.66 \\
\pm 0.66^{\mathrm{a}} \\
\end{array}$ & $\begin{array}{r}70.36 \\
\pm 0.72^{\mathrm{b}} \\
\end{array}$ & $\begin{array}{c}68.00 \\
\pm 0.81^{b}\end{array}$ & $\begin{array}{r}65.96 \\
\pm 1.04^{\mathrm{b}} \\
\end{array}$ & $\begin{array}{r}62.56 \\
\pm 1.07^{c} \\
\end{array}$ & $\begin{array}{r}67.91 \\
\pm 0.48^{\mathrm{A}} \\
\end{array}$ \\
\hline
\end{tabular}


Values are mean \pm SEM $(\mathrm{n}=120)$

Means having different capital $(\mathrm{P}<0.01)$ or small letters $(\mathrm{P}<0.05)$

within the same column or row are significantly different.

Table (4): Percentage of intact acrosomal membrane of buffalo spermatozoa immediately after dilution and after cooling at $5^{\circ} \mathrm{C}$.

\begin{tabular}{|c|c|c|c|c|c|c|c|}
\hline \multirow{2}{*}{$\begin{array}{c}\text { Semen } \\
\text { extender }\end{array}$} & $\begin{array}{c}\text { After } \\
\text { dilution }\end{array}$ & \multicolumn{6}{|c|}{ Storage time(hours) at $5^{\circ} \mathrm{C}$} \\
\hline & & 6 & 24 & 48 & 72 & 96 & $\begin{array}{c}\text { Overall } \\
\text { mean }\end{array}$ \\
\hline $\begin{array}{l}\text { Skimmed } \\
\text { milk }\end{array}$ & $\begin{array}{c}73.33 \\
\pm 0.93^{\mathrm{aB}}\end{array}$ & $\begin{array}{r}73.90 \\
\pm 0.83^{\mathrm{a}}\end{array}$ & $\begin{array}{c}71.83 \\
\pm 0.81^{\mathrm{a}}\end{array}$ & $\begin{array}{r}69.00 \\
\pm 0.82^{\mathrm{b}}\end{array}$ & $\begin{array}{c}66.40 \\
\pm 0.90^{\mathrm{b}}\end{array}$ & $\begin{array}{r}63.83 \\
\pm 1.01^{\mathrm{c}}\end{array}$ & $\begin{array}{r}68.99 \\
\pm 0.63^{\mathrm{B}}\end{array}$ \\
\hline $\begin{array}{c}\text { Tris } \\
\text { egg yolk }\end{array}$ & $\begin{array}{c}77.10 \\
\pm 0.78^{\mathrm{aA}}\end{array}$ & $\begin{array}{r}74.80 \\
\pm 0.75^{\mathrm{a}}\end{array}$ & $\begin{array}{r}72.83 \\
\pm 0.84^{\mathrm{a}}\end{array}$ & $\begin{array}{r}69.46 \\
\pm 0.96^{\mathrm{b}}\end{array}$ & $\begin{array}{c}66.55 \\
\pm 1.11^{\mathrm{b}}\end{array}$ & $\begin{array}{r}64.30 \\
\pm 1.26^{\mathrm{c}}\end{array}$ & $\begin{array}{c}69.59 \\
\pm 0.70^{\mathrm{AB}}\end{array}$ \\
\hline $\begin{array}{c}\text { Citrate } \\
\text { Egg yolk }\end{array}$ & $\begin{array}{c}78.00 \\
\pm 0.95^{\mathrm{aA}}\end{array}$ & $\begin{array}{c}76.16 \\
\pm 1.11^{\mathrm{a}}\end{array}$ & $\begin{array}{r}73.86 \\
\pm 1.12^{\mathrm{a}}\end{array}$ & $\begin{array}{c}71.33 \\
\pm 1.24^{\mathrm{b}}\end{array}$ & $\begin{array}{c}67.68 \\
\pm 1.39^{\mathrm{b}}\end{array}$ & $\begin{array}{r}66.96 \\
\pm 1.49^{c}\end{array}$ & $\begin{array}{r}70.80 \\
\pm 0.84^{\mathrm{A}}\end{array}$ \\
\hline
\end{tabular}

Values are mean \pm SEM $(n=120)$

Means having different capital $(\mathrm{P}<0.01)$ or small letters $(\mathrm{P}<0.05)$

within the same column or row are significantly different.

Table (5): Viability index of buffalo spermatozoa stored 96 hours after cooling at $5^{\circ} \mathrm{C}$.

\begin{tabular}{||l||c|}
\hline \multicolumn{1}{|c|}{ Semen extender } & Viability index \\
\hline \hline Skimmed milk & $112.26 \pm 3.09^{\mathrm{a}}$ \\
\hline Tris egg yolk & $116.06 \pm 3.78^{\mathrm{a}}$ \\
\hline Citrate egg yolk & $94.58 \pm 3.37^{\mathrm{b}}$ \\
\hline
\end{tabular}

Values are mean \pm SEM $(n=120)$

a-b: different superscripts indicate significant differences $(\mathrm{P}<0.01)$

\section{Conception rate of cooled buffalo semen:}

The conception rates after the first insemination were 50, 60 and 70 $\%$ for citrate egg yolk, skimmed milk and tris egg yolk extenders, $\overline{\text { Kafrelsheikh Vet. Med. J. Vol. } 6 \text { No. } 2 \text { (2008) }}$ 
respectively (Table 6). The conception rate of cooled buffalo semen was significantly $(\mathrm{P}<0.01)$ higher in tris diluted samples than skimmed milk and egg yolk citrate extended samples.

Table (6): Conception rates of buffalo cows artificially inseminated with cooled buffalo semen stored for 96 hours.

\begin{tabular}{|c||c||c||c||}
\hline \hline Semen extenders & $\begin{array}{c}\text { Number of } \\
\text { inseminated } \\
\text { buffalo cows }\end{array}$ & $\begin{array}{c}\text { Number of buffalo } \\
\text { cows that } \\
\text { conceived }\end{array}$ & $\begin{array}{c}\text { Conception rate } \\
(\%)\end{array}$ \\
\hline \hline $\begin{array}{c}\text { Tris } \\
\text { egg yolk }\end{array}$ & 20 & 14 & $70^{\mathrm{a}}$ \\
\hline Skimmed milk & 20 & 12 & $60^{\mathrm{b}}$ \\
\hline Citrate & 20 & 10 & $50^{\mathrm{c}}$ \\
\hline
\end{tabular}

a-c: different superscripts indicate significant differences $(\mathrm{P}<0.01)$

\section{DISCUSSION}

The ability of sperm to fertilize an ovum depends upon many factors which are probably an innate feature of the sperm and it is possible that they are altered by the procedures to which sperm are subjected following collection, such as dilution, cooling, freezing and thawing (Sharma et al.,1997). Proper semen storage and semen manipulation are very important to the success of artificial breeding livestock industries (Morrell and Hodges, 1998). All semen extenders are based on a particular buffer, which has provided the best results for a given species (Hopkins and Evans, 1989).

In the current study, the individual motility percentage of cooled buffalo semen was significantly $(\mathrm{P}<0.01)$ differed due to semen 
extenders. There was a significant difference in the percentage of individual motility between citrate egg yolk diluted samples in one side and each of skimmed milk and tris diluted samples on the other side with the lower values recorded for citrate diluted samples during the time of storage. The present results are in accordance with the results of Yassen and El-Kamash,(1970) and Kumar et al., (1994b) who reported that the motility percentage of cooled buffalo semen was significantly higher in skimmed milk than in citrate diluted samples.

Concerning the differences in the individual motility percentage between tris and citrate egg yolk samples during storage of cooled buffalo semen, the present results are in consistent with the results (Chinnaiya and Ganguli, 1980; Kumar et al., 1988; Kumar et al., 1994a; Rasul et al., 2001; El-Kishk, 2003) in buffalo which reported that the tris based extended samples showed higher sperm motility than citrate extended samples during storage at $5^{\circ} \mathrm{C}$. The present result contradicts the previous results (Rahman et al., 1988) which found that the percentage of individual motility of cooled buffalo semen was significantly higher in citrate than in tris extended samples.

The results of the current study indicated that there were no significant differences in the percentage of individual sperm motility between skimmed milk and tris extenders during storage time up to $72 \mathrm{~h}$. These findings are in agreement with the results of Kumar et al., (1992) who found that the decrease in sperm motility of buffalo semen stored at $5^{\circ} \mathrm{C}$ was similar in tris and milk up to $72 \mathrm{~h}$ and the best survival rate after $72 \mathrm{~h}$ was in tris buffer. Other results (El-Kishk, 2003) reported that the motility percentages of cooled buffalo semen were significantly higher in tris than skim milk diluted samples. 
The percentages of individual sperm motility of buffalo spermatozoa decreased significantly $(\mathrm{P}<0.05)$ with the advancement of storage time at $5{ }^{\circ} \mathrm{C}$. Similar results (Kumar et al., 1992; El-Kishk, 2003) were recorded in buffalo. The decrease in the percentage of sperm motility may be attributed to the decrease in the content of ATP which caused inactivated spermatozoa apparently incapable of resynthesizing ATP; this was accompanied by a precipitous fall in the rate of fructolysis (Salamon, 1970; Mann and Lutwak-Mann, 1981).

The percentage of alive sperm did not differed significantly due to semen extender during the first $24 \mathrm{~h}$ of storage. However, there was highly significant difference in the percentage of the alive sperm of cooled buffalo semen at $48 \mathrm{~h}$ of storage. Previous findings (El-Kishk, 2003) found that the percentages of alive sperm of cooled buffalo semen were significantly higher in tris than skim milk. Contradictory results (Bandyopadhyay and Mukherjee, 1985) found that the percentage of alive sperm was higher in citrate than tris extender. The advancement of cooled semen storage time decreased significantly $(\mathrm{P}<0.05)$ the percentage of alive sperm of cooled buffalo semen. These results are in agreement with those reported by other studies(Zeidan,1994; Ibraheam, 2006) The decrease in the percentages of alive sperm due to storage time may be due to accumulation of lactic acid which exerts a toxic effect on sperm cells and leakage of intracellular enzymes due to increased membrane permeability (Zeidan, 1994).

Our data revealed that semen extenders had no significant effect on the percentage of intact plasma membrane during the storage time. Previous results (Rasul et al.,2000) reported that the percentage of intact plasma membrane of buffalo spermatozoa did not differ due to buffering system (citrate, tris citric acid, tris-TES). With advancement of storage 
time the percentage of intact plasma membrane decreased significantly $(\mathrm{P}<0.05)$, these results are in consistent with the results (Rasul et al., 2001) which found that the percentage of intact plasma membranes of buffalo spermatozoa was reduced with the time of storage at $4^{\circ} \mathrm{C}$.

The results of the present study revealed that the percentage of intact acrosome of buffalo spermatozoa stored at $5^{\circ} \mathrm{C}$ was significantly ( $\mathrm{P}$ $<0.01)$ differed due to semen extenders with the highest values recorded for citrate followed by tris and skimmed milk extenders. These findings are in agreement with the results (Anzar and Graham, 1995) which reported that tris buffer, possibly due to its capacitating activity resulted in more damage to acrosomal cap compared to citrate. Contradictory results (Ibraheam, 2006) were obtained in buffalo semen. However, the percentage of intact acrosome of buffalo spermatozoa stored at $5{ }^{\circ} \mathrm{C}$ did not differ due to buffering system (Rasul et al., 2000) These differences in the results may be due to the species variation (Rasul et al., 2000). The percentages of intact plasma and acrosomal membranes significantly $(\mathrm{P}<0.05)$ decreased over storage time. These results are in agreement with the results (El-Kishk, 2003; Verberckmoes et al., 2005) reported in buffalo and bull semen.

The results of current study revealed that the viability index of buffalo spermatozoa after cooling at $5^{\circ} \mathrm{C}$ was significantly $(\mathrm{P}<0.01)$ higher in tris followed by skimmed milk and citrate extenders. Our findings may support the findings (khalifa, 2001;Tayseer and Khalifa, 2006) which reported that the viability index of frozen thawed buffalo semen was significantly higher in tris than citrate extender. Contradictory results (Ibraheam, 2006) found that the viability index of buffalo semen 
preserved at $5{ }^{\circ} \mathrm{C}$ for 5 days was significantly higher in skimmed milk than tris extender.

Our data showed that the first insemination conception rate of chilled buffalo semen was significantly higher in tris than skimmed milk and citrate diluted samples. The present findings are in accordance with the findings (Dhami and Kodagali, 1990) which found that the fertility of buffaloes inseminated with frozen thawed semen was significantly higher in tris based extender than citrate extender. Moreover, a higher conception rate for frozen bull semen was recorded (Wall and Foote, 1999) in tris than whole milk diluted samples. The higher post-thaw conception rate for frozen bull semen was recorded in skim milk followed by tris extender (Kalita et al., 1989). The conflicting data concerning the conception rate of extended buffalo semen may be attributed to species, storage time and type of semen. It could be concluded that the tris citric acid extender is the most satisfactory buffering system to improve the post-cooling semen quality in buffalo and gave the best fertility rate.

\section{REFERENCES}

- Amann, R.P and Hammerstedt, R.H. (1993): In vitro evaluation of sperm quality: An opinion. J. Androl., 14:397-400.

- Anzar, M. and Graham, E.F. (1995): Effect of filtration on post-thaw quality of bull semen. Theriogenology, 43:439-449.

- Bamba, K. (1988): Evaluation of acrosomal integrity of boar spermatozoa by bright field microscopy using an eosine-nigrosine stain. Theriogenology, 29:1245-1251. 
- Bandyopadhyay, S.K. and Mukherjee, A.K. (1985): Effects of semen diluents on the dimensional characteristics, proportions of live spermatozoa and spermatozoa with normal acrosome of buffaloes. Ind. J. Anim. Sci., 55:358-362

- Campbell, R.C.; Dott, H.N. and Glover, T.D. (1956): NigrosinEosine as stain for differentiating live and dead spermatozoa. J. Agric. Sci., 48(1):1-8.

- Chaudhari, S.U.R. and Mshelia, G.D. (2002): An overview of cryopreservation of cattle and buffalo bull semen. Int. J. Agri. Biol., 4 (4): 572-575.

- Cheema, A.A. and Samad, H.A. (1986): Performance traits of imported holestine-friesian cows in Quetta (Pakistan). Pakistan Vet. J., 33: 63-67.

- Chinnaiya, G.P. and Ganguli, N.C. (1980): Freezability of buffalo semen in different extenders. ZBI. Vet. Med A., 27:563-568.

- Davis, I.S. ; Bratton, R.W. and Foote, R.H. (1963): Livability of bovine spermatozoa at $5,-25$ and $-85 \mathrm{C}$ in Tris-buffered and citratebuffered yolk glycerol extenders. J. Dairy sci., 46:333-336.

- Dhami, A.J. and Kodagali, S.B. (1990): Freezability, enzyme leakage and fertility of buffalo spermatozoa in relation to the quality of semen ejaculates and extenders. Theriogenology, 34: 853-863.

- Dhami, A.J.; Sahni, K.L.; Mohan, G. and Jani, V.R. (1996): Effects of different variables on freezability, post thaw longevity and fertility of buffalo spermatozoa in tropics. Theriogenology, 46:109-120. 
- Dhami, A.J. ; Sahni, K.L. and Mohan, G. (1995): Effect of various extenders and additives on deep-freezing, enzyme leakage and fertility of bovine semen under tropical climate. Ind. J. Anim. Sci., 65: 20-23.

- El-Kishk, M.A. (2003): Physiological studies on farm animals, M.Sc. Thesis, Faculty of Agric. Mansoura univ. Egypt.

- Hopkins, S.S. and Evans, L.E. (1989): Artificial insemination. In: Veterinary Endocrinology and Reproduction. $4^{\text {th }}$ Ed. Mac Ddonald, L.E. and Pineda, M.H., (eds). Philadelphia, Lea and Feiberger.pp: 354-388.

- Ibraheam, A . A. (2006): Some studies for improving preservation and fertility of buffalo bull semen, M.V.Sc. Thesis, Zagazig univ. Egypt.

- Jeyendran, R.S.; Van der ven, H.H.; Perez-Pelaez, M.; Crabo, B.G. and Zaneveld, L.J.D. (1984): Development of an assay to assess the functional integrity of the human sperm membrane and its relationship to other semen characteristics. J. Reprod. Fertil., 70:219-225.

- Kalita, D.; Tomar, N.S.and Sharma, K.C.(1989):Studies on additives in Tris and milk diluents in relation to equilibration time for deep freezing of bull semen in liquid nitrogen. Ind. Vet. J., 66:418-421.

- Khalifa, T.A. (2001): Effect of some antioxidants on viability of preserved buffalo and ram semen. Ph.D Thesis, Fac. of Vet. Med. Cairo univ. Egypt.

- Kumar, S. ; Sahni, K.L. and Mohan, G. (1992): Effect of different levels of glycerol and yolk on freezing and storage of buffalo semen in milk, Tris and sodium citrate buffers. Buffalo J., 2: 151-156. 
- Kumar, S.; Sahni, K.L. and Mohan, G. (1994b): Effect of different sugars as a sole cryoprotectant during refrigeration and preservation of buffalo semen. Ind. J. of Anim. Sci., 64: 471-473.

- Kumar, S.; Sahni, L.P.; Mohan, G. and Sahni, K.L. (1994a): Effect of different concentrations of yolk and glycerol on cryopreservation of cattle semen in milk, tris and citrate dilutors. Ind. J. of Anim. Sci., 64:827-830.

- Kumar, S.; Verma, M.C.and Tripathi, S.S.(1988): Comparative study on freezability and effect on physico-morphological characteristics of Murrah bull semen in different diluters. Ind.J.Anim. Sci.,58:771-773.

- Mann, T. and Lutwak-Mann, C. (1981): Male Reproductive Function and Semen. Springerverlag, Berlin Heidelberg, New York, PP: 264.

- Milovanove, V.K. (1962): Biology of Reproduction and Artificial Insemination of Farm Animals. Moscow, Izdatelstvo Selskokhoziastvennoi Literatury, pp: 392-419.

- Morrell, J.M. and Hodges, J.K. (1998): Cryopreservation of non human primate sperm: Priorities for future research. Anim. Reprod. Sci., 53:43-49.

- Rahman, A.; Dutta, J.C. and Rajkonwar, C.K. (1988): A study on preservation of buffalo semen in two extenders. Buffalo J., 4:57-60.

- Raizada B.C.; Sattar, A. and Pandey, M.D.(1990): A comparative study of freezing buffalo semen in two diluters, In: R.M. Acharya, R.R., Lokeshwar, S. Kumar (Eds.), Recent freezing and storage of buffalo semen in milk, Tris and sodium citrate buffers. Buffalo J., $2: 151-156$. 
- Rasul, Z.; Ahmad, N. and Anzar, M. (2001): Changes in motion characteristics, plasma membrane integrity, and acrosome morphology during cryopreservation of buffalo spermatozoa. J. Androl., 22 (2): 278-283.

- Rasul, Z.; Anzar, M.; Jalali, S. and Ahmad, N. (2000): Effect of buffering systems on post-thaw motion characteristics, plasma membrane integrity, and acrosome morphology of buffalo spermatozoa. Anim. Reprod. Sci., 59:31-41.

- Salamon, S. (1970): The survival of ram spermatozoa following pellet freezing below -79 $\mathrm{C}^{\mathrm{o}}$. Australlin J. Biological Sci., 23:459-468.

- Sansone, G.; Nastri, M.J.F. and Fabbrocini, A.(2000): Storage ofbuffalo (Bubalus bubalis) semen. Anim. Reprod. Sci., 62: 55-76.

- Sharma,R.K.; Vemulapalli,S.;Kohn,S.and Agarwal,A. (1997): Effect of centrifuge speed, refrigeration medium and sperm washing medium on cryopreserved sperm quality after thawing.Arch.Androl.,39:33-38.

- Sukhato, P.; Thongsodseang, S.; Utha, A. and Songsasen N. (2001): Effects of cooling and warming conditions on Post-thawed motility and fertility of cryopreserved Buffalo spermatozo. Anim. Reprod. Sci., 67: 69-77.

- Tayseer, I.M. and Khalifa, T.A.A. (2006): Assessment of the fertilizing potential of frozen bovine spermatozoa by different in vitro techniques. Kafr EL-Sheikh Vet. Med. J., 4(1):801-816.

- Vale, W.G.; Ohashi, O.M.; Sousay, J.S. and Ribeiro, H.F.L. (1990): Studies on the reproduction of water buffalo in the Amazon basin. In Livestock Reproduction Latin America. FAO/LAEA semina (Bogotá).PP:201-210. 
- Verberckmoes, S.; Van Soom, A.V.; Dewulf, J. and Kruif, A.D. (2005): Comparison of three diluents for storage of fresh bovine semen. Theriogenology, 63: 912-922.

- Wall, R. J. and Foote, R. H. (1999): Fertility of Bull Sperm Frozen and Stored in Clarified Egg Yolk-Tris-Glycerol Extender. J. Dairy Sci., 82:817-821.

- Yassen, A.M. and El-Kamash, M.A. (1970): Storability of buffalo bull sperm in skim milk extenders. Alex. J. Agr. Res., 18:7-12.

- Zeidan, A.E.B. (1994): New aspects in freezing cattle semen. Ph. D. Thesis, Fac. of Agric., Zagazig Univ. Egypt.

تأثثير المخففات على خصائص وخصوبة السائل المنوى المبرد لطلائق الجاموس

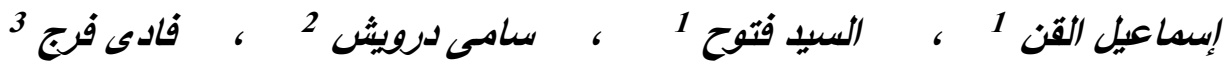

1 قسم التوليد والتناسل والتلقيح الاصطناعى بكلية الطب البيطرى- جامعة كفر الثيخ

2 مزرعة محلة موسى - معهد بحوث الانتاج الحيوانى

$$
3 \text { مديرية الطب البيطرى بالغربية }
$$

أجريت هذه الدراسة لمعرفة تأثير المخفقات على خصائص و معدل الخصوبة السائل المنوى

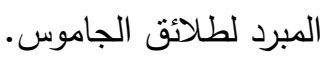

- - تم تجميع السائل المنوى مرتين أسبوعياً باستخدام المهبل الصناعى من خمسة طلائق جاموس تتراوح

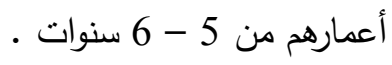

- - تم التقييم للسائل المنوى بعد التجميع لاختيار القذفات المناسبة للتبريد

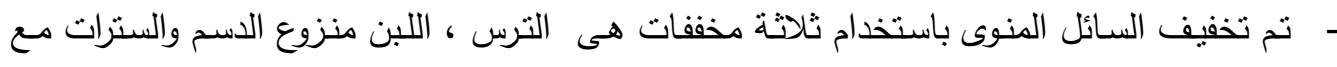

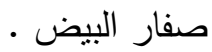

- تم تبريد السائل المنوى ببطء الى درجة 5م وتم تقييم السائل المنوى المبرد يوميا بعد 24،6، 48، 72 96،

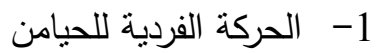




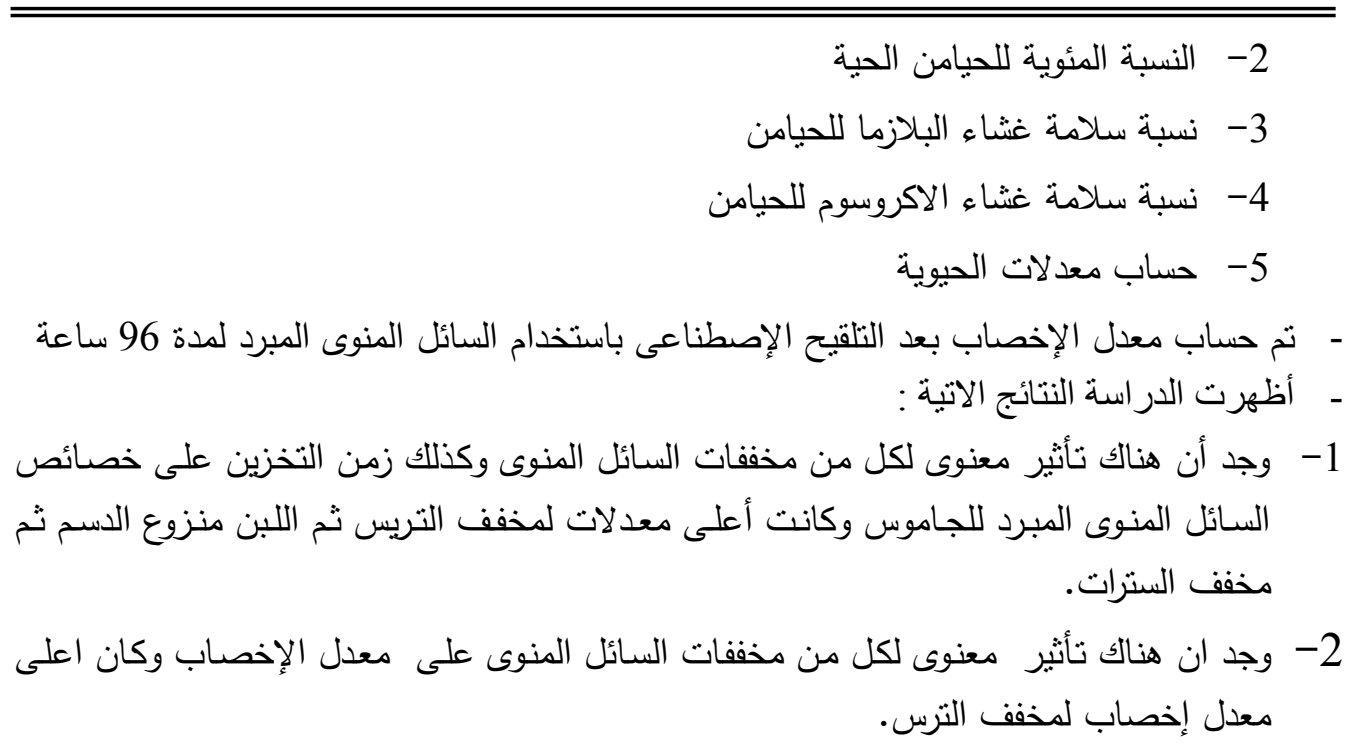

